\title{
Article
}

\section{Changing Tides of the Chinese Trademark Law}

\author{
Haijun $\mathrm{Lu}^{*}$
}

Trademark law is but part of competition law. With a good faith clause, the new Chinese trademark law moves closer to competition law. The new law is more liberal to the registrable signs with more non-traditional signs such as sound marks and flora in the family of registrable signs. Some kind of bona fide prior use of trademark is respected and the requirement of trademark use is strengthened in the new law. The likelihood of confusion has been absorbed in the new law as the prerequisites trademark infringement other than using identical marks on identical goods or services. In the new law, a clause against using well-known trademarks as tool to promoting products is formulated. Changes on the procedures of oppositions to trademarks witness the efforts to simplify the examination of trademarks. The stronger protection efforts such as punitive damages in the new law will go against trademark infringement.

Keywords: Chinese Trademark Act, Good Faith Clause, Use of Trademark, Likelihood of Confusion, Well-Known Trademark

\section{INTRODUCTION}

The Chinese Trademark Act (中华人民共和国商标法) was enacted in 1982 and revised in 1993, 2001 and 2014. In this course, there has been notable progress in trademark protection which vigorously promote China's economic development. By the end of 2014, there were a total of 15,226,700 trademark applications,

\footnotetext{
* Associate Professor of Law at the University of International Business and Economics ("UIBE"). LL.M./Ph.D. (Zhongnan Univ. of Economics and Law). This paper was supported by UIBE research fund (XK2014406). http://orcid.org/0000-0002-3584-4276 The author may be contacted at: shangbaking@126.com / Address: UIBE Law School, No. 10, Huixindong Street, Chaoyang District, Beijing 100029 P.R. China
} 
10,027,500 trademark registrations and 8,930,000 legitimate registered trademarks; all among the first in the world. In the same period, however, some problems remain unsettled including cumbersome trademark registration procedures, bad-faith-registration, and a large number of trademark infringements calling for reform of trademark law. ${ }^{1}$ In August 30, 2013, the fourth meeting of the second session of the Chinese National People's Congress ("NPC") passed the Decision on Amending $<$ People's Republic of China Trademark Law $>$ (矢 于修改〈中华人民共和国商标法〉的决定) (主席令第六号). ${ }^{2}$ It finally came into force on May 1, 2014. The 2014 amendment of the Chinese Trademark Act (hereinafter the new law) includes 53 modifications with 73 sections in contrast to 64 sections in the Chinese Trademark Act (2001) (hereinafter the old law). The amendments mainly concern the efficiency of trademark registration, stronger protection of trademarks and the establishment of a fair competitive market. In addition, various supplementary regulations including new updates to the Trademark Law Implementing Regulations, ${ }^{3}$ separate Guidelines and Notifications issued by the Trademark Review and Adjudication Board ("TRAB") ${ }^{4}$ and Judicial Interpretations on jurisdiction and other issues from the Supreme People's Court ("SPC") ${ }^{5}$ together constitute the whole trademark system of China.

The primary purpose of this research is to introduce the pertinent provisions in the new law along with some comments. This article is composed of nine parts including short Introduction and Conclusion. Part two will discuss the integration of Chinese trademark law within competition law. Part three will discuss the inception of the non-traditional trademarks such as sound marks in the new law. Part four will talk about the efforts of balance of use-dominated formula and registration-dominated formula in the new law. Part five will tackle the rational regression of the new law from similarity-of-signs test to likelihood-of-confusion test in the judgment of trademark infringement. Part six will investigate wellknown trademarks and a remarkable concern of foreigners considering the protection of un-registered trademarks in China. Part seven will examine the simplified procedure of examination focusing on the change of the procedure of opposition to trademarks. Part eight will search for the way how to strengthen protection efforts such as punitive damages, in the new law. 


\section{Trademark Law as Part of Competition Law}

"The law of trade-marks is but a part of the broader law of unfair competition...",

The old law had not realized the nexus between trademark law and competition law, thereby yielding it a narrow focus. First, a strict first-to-file doctrine is rooted in all of the old law. Based on this doctrine, trademark rights especially registered trademarks, have been deemed as absolute private rights. ${ }^{7}$ The old law goes astray by treating trademark rights similar to other kinds of intellectual property such as copyright and patent. ${ }^{8}$ Investments on works and invention need be protected with strong property rights as incentives. It is, however, not the same case in trademark rights. ${ }^{9}$ Second, trademarks have been isolated from other kinds of sources, indicating signs such as trade dress, business name, domain name, etc. As a matter of fact, from the perspective of competition law, all the above signs cannot be used with the effect of confusing or misleading consumers. In the old law, however, new lines need to be defined with a rather positive sign. In the perspective of trademark law as absolute private law, facing new environment, whether the rightholder of trademark is entitled to prohibit others from using his/her mark in the new environment is to be examined without justified answers. Under the regime of competition law, however, whether others' trademark use results in likelihood of confusion or succeeds in misleading is to be examined with clear conclusions. E.g., using trademark as part of a domain name, with the likelihood of confusion or misleading should be inhibited because it is obvious 'unfair competition.' Recognizing the above truism, many seemly thorny problems become apparent; what is the justified fundament of an exclusive right of a trademark? General parlance for 'Coca-Cola' has changed to 'Coke.' If someone else uses 'Coke' on identical or similar goods or services could 'Coca-Cola' as a Company, sue for trademark infringement? ${ }^{10}$ In addition, how are the damages for infringement of trademark reasonably determined? Only by laying trademark law on the strong foundation of competition law, then, the above problems could easily be tackled. The right-holders of a trademark do not create the right. The right is protected for fair competition in the market and for the protection of consumers. In essence, trademark rights are rooted in the market (i.e., the perception of consumers). ${ }^{11}$ In case of nicknames, although it is the public rather than the right-holders of the 
trademark, who have created the mark (in some special cases, the right-holders even publicly state that the products should not be called by the nickname), ${ }^{12}$ the right-holders obtain exclusive rights on the nickname because consumers have associated the nickname exclusively with the product in question. Otherwise, consumers are bound to be confused. In addition, under the regime of competition law, trademark law does not construct an absolute private right rather than that of maintaining a fair competition market (i.e. the ultimate end) through the protection of a private right (i.e. the direct end). Trademarks are not being protected in order to encourage creation of more trademarks. ${ }^{13}$ If the right-holder of a registered trademark does not use the trademark in commerce and the user has used the trademark with enormous economic benefits, ${ }^{14}$ the question arises as to whether there are damages that ought to be considered yet again. ${ }^{15}$ To say the least, if there are damages, the amount of damages should not be calculated based on the profit earned from the infringing act concerning the function of a trademark; ${ }^{16}$ the rights of trademark otherwise shall occur as an absolute, but unreasonable private right.

\section{A. Good Faith Clause}

A good faith clause has been added in the new law ${ }^{17}$ which is a general clause with roots in competition law. ${ }^{18}$ By virtue of being the emperor-type clause, although some kinds of bad-faith trademark registration or other kinds of unfair competition may not be clearly defined in the new law, it shall be rejected on the good faith clause. Perhaps in the future, the good faith clause shall be exercised as a fallback provision. Under the wide-ranging vision of competition law, trademark should only be considered as one of the several tools to maintain, for a fair competitive market and the shield of the legitimate rights of consumers. Whether the use of a certain mark should be refused must be judged on whether a fair competitive market occurs and whether the consumers are being confused or misled. Retrospectively, a good faith exercise of trademarks rights should promote a fair competitive market and the protection of consumers.

\section{B. Settlement of the Conflict between Trademark and Business Name}

In a market, the trademark is not alone. There are many other kinds of signs such as a 'trade dress' which has a source indicating function. In addition, trademark and business names all relate to the source of goods or services. If the registered 
trademark or unregistered well-known trademark is used as the business name by another party, the consumer may be confused about the source of goods or services. Treating trademark as the only source indicator without considering other signs could mean the end of trademark law, ${ }^{19}$ which cannot be realized. In the old law, there is no special clause settling the conflict of trademark and business name. ${ }^{20}$ Moreover, in China, the registration of a business name is largely regional. However, the registration of trademark is nationwide. [Emphasis added]

In the new law, notably, if the registered trademark or the unregistered well-known trademark is used as the business name with the intended effect of misleading consumers, the behavior is unfair competition under the regime of Chinese Anti-Unfair Competition Law. ${ }^{21}$ The new law has occurred as the family member of competition law in which all the signs indicating the sources of goods or services should not be missed in the establishment of a fair competitive market. The signs such as trade dress, albeit unregistered, should be protected against likelihood of confusion or misleading.

\section{From Visible-Sign to Sound Marks}

"It is the source-distinguishing ability of a mark - not its ontological status as color, shape, fragrance, word, or sign - that permits it to serve these basic purposes." 2

Sound is without borders. Sound marks may be the darling of enterprises based on to develop the international market. ${ }^{23}$ The old law prohibited the registration of sounds, because a sound cannot be a visible sign in and of itself. ${ }^{24}$ The digital era especially the occurring of e-commerce calls for the Chinese society to legitimatize sound marks as a trademark. Sound marks ${ }^{25}$ which have been used widely as non-traditional trademarks ${ }^{26}$ have been finally added in the new law. ${ }^{27}$ That is an opportunity especially for the high tech enterprises, as well as a challenge to Chinese trademark registration and protection.

\section{A. Registration}

There are two kinds of sound marks legal systems such descriptive representation systems (US) and graphic representation systems (EU). ${ }^{28}$ In both the systems 
above, the requirements of descriptions should be intelligible to competitors and the public, thus delineating the rights held by each trademark. ${ }^{29}$ Similar to the American practice, ${ }^{30}$ a required specimen of sound, plus a description of the marks should be submitted to the Chinese Trademark Office ("CTO"). ${ }^{31}$ The sound may be described in onomatopoeia, listed musical notes, and simple declaratory phrases. ${ }^{32}$ As mentioned, intelligibility is the touchstone for the requirements of descriptions. ${ }^{33}$ In general, stave and sonogram are considered to be intelligible. ${ }^{34}$ Mere written descriptions themselves such as "the sound of a cockcrow" is not clearly defined in the sense of sound marks registration. ${ }^{35}$ A sequence of musical notes without pitch or duration is not intelligible. ${ }^{36}$

\section{B. Distinctiveness}

Different from common visible sign, it is difficult for a common sound mark to be impressed on people's minds. ${ }^{37}$ A sound mark should be able to indicate a source and distinguish goods or services of one undertaking from those of other undertakings (i.e. distinctiveness) to be registrable. The burden of proof is on trademark applicants. ${ }^{38} \mathrm{~A}$ mark may be inherently distinctive or acquire distinctiveness through consistent use in commerce. ${ }^{39}$ Similarly, a sound should be inherently distinctive ${ }^{40}$ or commonplace sounds that have acquired distinctiveness (secondary meaning) ${ }^{41}$ to have the ability to indicate a source and to distinguish goods or services. ${ }^{42}$ Sounds are deemed inherently distinctive if they can immediately convey the source of a product or service to consumers. ${ }^{43}$ A sound mark acquires a secondary meaning when the consumers recognize and associate the sound exclusively with a single source. ${ }^{44}$ The sound may be music composition (most compositions are very short), actual sounds or imitation of actual sounds. Whether a sound mark is distinctive should be decided in the special context of goods or services on which the mark is used or proposed to be used. ${ }^{45}$ The roar of a lion, e.g., may be distinctive being used on the goods such as cinematographic works (the lion roar of MGM has been registered). ${ }^{46}$ When a lion roar is used on the service of a zoo, however, the requirement of distinctiveness is difficult to meet. Another example, a cockcrowing voice may be distinctive when it is used on the goods such as software. In contrast, when the cockcrowing voice is used on the services such as selling chicken or eggs, meeting of the requirement of distinctiveness should be thought again. In the case of sound 
marks, in general, the marks acquire distinctiveness through long time uses (i.e. acquiring a secondary meaning). Some cases argue that, only when sounds made by a product during its normal course of operation acquires distinctiveness, they can be registrable. ${ }^{47}$ Some commentators even argue that only the marks' acquired secondary meaning are registrable. ${ }^{48}$ The arguments are a little bit absolute which has been challenged. ${ }^{49}$ However, it may be the actual practice of sound mark registration. E.g., MGM needed about 60 years to register the lion roar. ${ }^{50}$ In the future, in Chinese trademark practices, the important role of uses on acquiring of distinctiveness should be emphasized. About the sound marks, if there are any doubts about the inherent distinctiveness of the marks, a proof of acquired distinctiveness is required. ${ }^{51}$ In the near future, there would be some sound marks registration application to CTO. The Organization should be thus prepared to examining sound marks. In order to answer those questions - which sound marks are distinctive? or which sound marks are non-distinctive?-, a fundamentally sound set of criteria should be drawn. It should be noted that even in the most liberal nations in regards to recognizing the registration of sounds (i.e. the US), ${ }^{52}$ only hundreds of sound marks are registered. ${ }^{53}$ There is also a very small scale of registered sound trademarks around the world. ${ }^{54}$ CTO should, ideally, be stingy in awarding registered sound marks following the practice of the world about sound marks and other kinds of non-traditional signs. ${ }^{55}$

\section{Functionality}

The functionality doctrine comprises of utilitarian and aesthetic functionality. ${ }^{56} \mathrm{~A}$ mark containing a product feature which is essential to the use or purpose of the article or affects the cost or quality of the article is 'utilitarianly' functional, ${ }^{57}$ while a mark containing an aesthetic element that makes the product more attractive to consumers is 'aesthetically' functional. ${ }^{58}$ If the exclusive use of the feature would put competitors at a significant non-reputation related disadvantage, the feature is functional. ${ }^{59}$ In deciding whether a mark is functional, the following factors should be considered:

1. "the existence of an expired utility patent... disclose[ing] the utilitarian advantage of the design";

2. advertizing material in which "the originator of the design touts [the design's] utilitarian advantages"; 
3. the availability of alternate designs to competitors; and

4. whether the alternate designs provide competitors with comparatively simple and cheap methods of manufacturing the product. ${ }^{60}$

If a sound mark is functional, it is unregistrable. ${ }^{61}$ The above-mentioned factors may be helpful in judging whether a sound mark is functional. 'Potato,' a sound from an exhaust pipe based on the particular configuration of a motorcycle, ${ }^{62}$ is unregistrable due to functionality concerns. If the sound is registered, the monopoly of the particular configuration of a motorcycle shall be obtained through a trademark. ${ }^{63}$ It is the specialty of patent law, however. ${ }^{64}$ Although the unique sound created by products or services recognized by consumers as indicating sources is registrable, ${ }^{65}$ in general, if a sound originates in the particular configuration of a product, we should be cautious to grant the sound a trademark because of the possible functionality of the sound. If a sound mark is functional, it is generally unregistrable even with the show of acquired distinctiveness or the competition will be inhibited. ${ }^{66}$ If a sound has been created for distinctive goods or services and has nothing to do with the function of the goods or services, however, it is registrable. A sound being programmed into a particular product's software, is registrable although it is in a product's normal course of operation. ${ }^{67}$

\section{Similarity}

Similarity of signs is one of the several important factors in determining whether there is a likelihood of confusion. In the case of traditional visible signs, in determining whether there is a likelihood of confusion, the marks should be considered in their entire ties affording greater weight on the dominant component of the marks. ${ }^{68}$ The tests for a likelihood of confusion should be abided by in the case of sound marks. There are, however, obvious differences between sound marks and traditional visible signs. It is difficult to dissect a sound mark into dominant components and non-dominant components. Thanks to new technologies, sound marks can be also distinguished in an easier manner. Concerning the function of trademarks and the habits of consumers, however, we should not rely on comparison of machines to decide whether the sound marks are similar. Albeit there are differences between two sound marks, the similar total concept and feel may confuse consumers about the source of goods or services. Concerning the test of likelihood of confusion, the similarity should be examined 
on the basis of an average consumer's total concept and feel rather than the dissection $^{69}$ of a machine.

It is worth noting that, except sound marks, based on the provisions of the Chinese new trademark law, ${ }^{70}$ other kinds of non-traditional and non-functional trademarks such as flora are also registrable with acquiring distinctiveness because most of flora are not inherently distinctive. ${ }^{71}$

\section{BALANCE OF REgistRation-DOMINATED Formula ANd Use-Dominated Formula}

“...the right to a particular mark grows out of its use, not its mere adoption..."

"...to create trademark or trade dress rights, a designation must be proven to perform the job of identification: to identify one source and distinguish it from other sources." $"$ "73

Use of signs is the fundamental justification for awarding exclusive rights of trademarks ${ }^{74}$ especially in the context of common law. ${ }^{75}$ In the use-dominated formula such as the US law, practical use or intention to use a trademark is the prerequisite to obtain an exclusive right to a trademark. ${ }^{76}$ Even in the traditional registration-dominated formula ${ }^{77}$ such as the law of Germany, the use of trademark is one of the several origins of the exclusive rights of trademark. ${ }^{78}$ In general, there are use requirements of signs, because without use of a sign, the sign does not function as a trademark. ${ }^{79}$ This is also true in Chinese trademark law. ${ }^{80}$

\section{A. Definition of Contextual Trademark Use}

"Trademark use is a basic element of all provisions relating to trademark rights and infringement." $" 81$

In the new law, "trademark use in the context of trademark law" (hereinafter trademark use) has been clearly defined as being indicative of the sources of the goods or services. ${ }^{82}$ The provision of the definition of 'trademark use' is very important. First, although a trademark should be registered for an exclusive right of use, ${ }^{83}$ practical use of trademark is decisive in the maintenance of the 
exclusive right. ${ }^{84}$ In China, if there is no justification for non-use of trademark for three consecutive years, the trademark can be cancelled. ${ }^{85}$ Some companies try to maintain the validity of their registered trademark by using it on some media such as an unknown tabloid without the effect of indicating the sources of goods or services (i.e. merely to reserve a right in a mark). ${ }^{86}$ There may be some confusion about whether the above-mentioned use of trademark can maintain the validity of the registered trademark without the definition of 'trademark use' in the new law. It is, however, obviously not a legitimate 'trademark use' in the context of the new law. Second, prior proper use of trademark and a trademark infringement defense based on non-use of registered trademarks have been added in the new law. They are important balance mechanism which shall be effective only by clearing the definition of 'trademark use.' If the prior user of a mark has not used the mark indicating the sources of goods or services, it is not justified to approve his/her rights in the mark. Take another example. If the plaintiff has not used his/her registered trademark in the sense of indicating the sources of goods or services, it is difficult to argue that there are any damages to the plaintiff with the use of the mark by the defendant. Finally, other than using trademarks in the sense of indicating the sources of goods or services, there are many other kinds of trademark utilization such as using surname on a paper or using a sign (like in the BMW example) to mark that the service of BMW cars repairing will be provided. Some scholars argue that aforementioned trademark uses belong to fair use/fair dealing of trademarks, ${ }^{87}$ which is logically true. The justification for freedom of using trademarks is not fair use/fair dealing, a copyright law terminology. Only misuse of a mark causing the actual confusion will be prevented. ${ }^{88}$ Pursuant to the definition of 'trademark use' in the new law, all of above mentioned trademark uses are not 'trademark use.' This means that the signs are not used to indicate the sources of goods or services. An example is to use 'BMW' to mark that the service of BMW cars repairing is not indicative of the sources of BMW cars. Then, it is not necessary to rely on the fair use/fair dealing doctrine to award freedom to the other kinds of trademark use except the 'trademark use.' 'Trademark use' in the sense of trademark infringement should conform to 'trademark use. ${ }^{89}$ In other words, if a trademark use does not meet the likelihood of confusion test, freedom should be given to the use. In another similar instance, using trademarks of plaintiffs on the website of the defendant may constitute trademark infringement. 
Using the trademarks of plaintiffs in the 'post-domain path' of certain webpages on the defendant's website, however, shall not constitute trademark infringement. ${ }^{90}$ Facing new problems under a new environment such as that in the digital era, the truism being that the "only source identifying uses qualify as trademark uses" should be abided by to tackle the seemingly new problems.

\section{B. Prior Bona Fide Use of a Trademark}

"...The owner of a trade-mark may not, like the proprietor of a patented invention, make a negative and merely prohibitive use of it as a monopoly..." 92

From a global perspective, obtaining rights of trademark through trademark use has been accepted by most trademark legislations. ${ }^{93}$ In the old law, based on the absolute doctrine of obtaining-exclusive-rights-of-trademark-on-registration, ${ }^{94}$ it is impossible for a party to obtain an exclusive trademark right through trademark use although there are some provisions ${ }^{95}$ protecting holders of unregistered trademarks. Following these provisions, unregistered trademarks shall be protected as follows:

1. Unregistered Well-Known Trademarks. A trademark which constitutes a reproduction, an imitation, or a translation, liable to create confusion, of an unregistered well-known mark shall be refused the registration, and to prohibited the use;

2. Unregistered Widely-known trademark to some extent. If a prior used unregistered trademark has a certain influence on consumers (hereinafter widely-known trademark in some extent), ${ }^{96}$ the trademark shall not unfairly ${ }^{97}$ registered preemptively by other parties; ${ }^{98}$ and

3. Unregistered Ordinary trademarks. If the applicant knows or should know the prior used trademark, the unfairly registered trademark on other party's prior used trademark shall be cancelled. ${ }^{99}$

Albeit the above provisions are about unregistered trademarks, some blurred problems remain unsettled: (1) If a mark is neither well-known trademark nor widely-known trademark in some extent and there is no bad-faith registration, the applicant will obtain a registered trademark. The question remains as to whether 
prior use of the mark can continue its use in commerce; and (2) if no one has registered the previously used mark, and someone else uses the unregistered mark in commerce causing a likelihood of confusion, can the previous user sue for trademark infringement?

The purpose of trademark law is to guarantee fair competition for the protection of legitimate interests of consumers as a whole rather than the exclusive rights of some individuals or entities. If others sell identical or similar goods or services under the identical or similar signs of the trademark holder without a likelihood of confusion of consumers, it is not justified to prohibit the bona fide use of signs by the parties, other than those of the trademark holders. Concerning the important role of the use of sign, in obtaining an exclusive right of a trademark, the new law defines a prior proper use of trademark as being legitimate with the effect of co-existing of trademark in some special contexts. ${ }^{100}$ In the context of the new law, the first problem, however, has been settled giving rise to some new concerns. First, the right-holder of a widely-known previously used trademark may continue to use the trademark within the scale of the original use subject to some requirements (e.g., with distinct marks on demand). ${ }^{101}$ Second, the rightholder of an ordinary prior used trademark may not continue to use the trademark which has been bona fide registered by another party. Third, the key issue of "the scale of the original use" remains unclear. Some scholars argue that the prior user should limit his/her use to the identical goods or services rather than expanding it to similar goods or services (not to mention non-similar goods or services) ${ }^{102}$ and the original specific regions. ${ }^{103}$ Others claim that the prior user may use the mark beyond the original product scale and original specific regions. ${ }^{104}$ Considering the protection of consumers as the end of trademark law, the prior users' expansion in the scale and scope of operations depends on whether the trademark use in the above context will cause a likelihood of confusion. Therefore, if a likelihood of confusion does not exist, the prior user can use the mark beyond the original product scale and original specific regions. In the case of holders of registered trademark limiting their commerce within specific product scale and regions or failing to occupy a large market share, it is unjustified to limit the prior user for the use of trademarks. Fourth, the provision of prior bona fide use of a trademark in the new law does not abide by the priority principle. In the priority principle, the prior user as a senior user, has an exclusive right in general. ${ }^{105}$ In the new law, 
however the prior user has trademark rights only in exceptional circumstances with a series of prerequisites. Addressing the second question, in general, if the mark is a well-known trademark or widely-known trademark to some extent, there is a strong possibility that the use of the mark by the latecomer may cause a likelihood of confusion. ${ }^{106}$ In this circumstance, based on the right or legitimate interests originated from the prior use (i.e., the priority principle that the prior or senior user has superior rights in the mark ${ }^{107}$ when the mark has not been registered in the context of Chinese trademark law), the prior user can sue the latecomer for trademark infringement. ${ }^{108}$ If the mark is an ordinary trademark and a likelihood of confusion does not exist, however, the co-existing ${ }^{109}$ of trademarks should be approved by law.

\section{Not Using Registered Trademark as a Trademark Infringement Defense "...There is no such thing as property in a trade-mark except as a right appurtenant to an established business or trade in connection with which the mark is employed..." 110}

There is no property ${ }^{111}$ in a trademark in gross. ${ }^{112}$ Concerning the essential role of trademark use in obtaining an exclusive right of a mark, the plaintiffs' trademark infringement allegations may be rejected on the grounds that the plaintiffs have not used the marks adequately ${ }^{113}$ because the trademark owner has a property right only when it is necessary to prevent customer confusion. ${ }^{114}$ If the trademark owner has not adequately used the mark, however, there will be no customer confusion. According to the above truism, in the new law, if someone registers a trademark but hung it up (there is no actual confusion in this circumstance), ${ }^{115}$ others who use the same trademark without damages to the holders of registered trademark are not liable for damages. ${ }^{116}$ This is a notable progress in the Chinese legislation of trademark. Some problems, however, still remain unclear. An Individual or entity, which has not practically used his/her trademark to indicate the source of goods or services, does have a true plan to use the trademark in the future. If his/ her registered trademark has been used by another party in commerce as indicative of the sources of goods or services, based on the definition of trademark use in the new law, whether the true plan to use a trademark is a kind of source indicating trademark use? In general, one party may have a plan to use a mark in the future. 
A bona fide use plan of a mark should be respected. In the case of bon a fide use plan of mark, the requirement of 'trademark use' should be presumably met. The trademark infringement defense based on "there is no trademark use" should be thus rejected.

\section{From the Similarity of Signs Test to the LIKELIHOOD-OF-CONFUSION TEST}

"Likelihood of confusion" $" 117$ is the fundamental criteria in judging a trademark infringement. ${ }^{118}$ A likelihood of confusion should be decided by the following factors: (1) the strength of the mark; (2) the similarity of the marks; (3) the proximity of the goods or services; (4) the intent of the accused; (5) evidence of actual confusion; (6) the marketing channels used; (7) the likelihood of expansion into other markets; and (8) the degree of care purchasers are likely to exercise. ${ }^{119}$

The similarity of signs could lead consumers to confusing the sources of goods or services. However, it is not necessarily as such because a likelihood of confusion is also based on factors other than the similarity of signs. ${ }^{120} \mathrm{~A}$ likelihood of confusion should be examined when the marks are encountered in the marketplace. ${ }^{121}$ Taking account of the special context, a simple similarity of signs may not be a likelihood of confusion. ${ }^{122}$ Moreover, whether goods or services are identical or similar should be considered in determining a likelihood of confusion. ${ }^{123}$ In other words, confusing similarity of signs rather than simple similarity of signs shall be a critical ground for arguing trademark infringement. [Emphasis added] Moreover, the "Likelihood of Confusion Test" shall limit monopolistic trademark rights to a reasonable scale. ${ }^{124}$

Let's take a look at the factors in determining a likelihood of confusion. If using identical signs on identical goods or services, a likelihood of confusion exists. However, unless using identical signs on identical goods or services, taking account of the special context in which the signs are encountered in the marketplace, a likelihood of confusion does not necessarily exist. Rightly recognizing the above-mentioned points, in the new law, except using the identical sign on the identical category of goods, in the case of other kinds of trademark uses (e.g., using the identical sign on the similar category of goods, using the similar sign on 
the identical category of goods and using the similar sign on the similar category of goods), a likelihood of confusion should be proven to support an argument of trademark infringement. ${ }^{125}$ In other words, albeit using the identical sign on the similar category of goods, if there is no likelihood of confusion, it is not trademark infringement. Later, the plaintiff should prove existing the likelihood of confusion in the other kinds of trademark using except for using the identical sign on the identical category of goods to compensate for their damages.

\section{Well-known Trademarks: From Honor to Reference Factors in RULING}

The Chinese Trademark Act of 1993 did not touch a well-known trademark based on a strict first-to-file system. ${ }^{126}$ Although there was not a legal term, "well-known trademark" in the Chinese Trademark Act of 1993, it was the first law to protect well-known trademarks. ${ }^{127}$ Registration of another party's well known trademark in violation of the principle of good faith is designated as being deceptive or an improper means of trademark registration in the context of Article 27(1) of the Chinese Trademark Act of $1993 .{ }^{128}$ Following those rules, some applications to register other parities' well-known trademark such as 'VOLVO' on non-similar goods or services have been rejected. ${ }^{129}$

In essence, well-known trademarks are mainly crafted to protect unregistered trademarks. ${ }^{130}$ The ever-expanding scope has been witnessed in international law regarding well-known trademarks. ${ }^{131}$ Well-known trademarks were first incorporated in the Chinese Trademark Act of 2001. ${ }^{132}$ The establishment of the system of well-known trademarks guarantees protection of well-known trademarks, especially those unregistered and well-known to some extent. At the same time, some controversial matters remains unsettled. If a trademark is wellknown in Europe, but not known to almost everyone in China, can the trademark be protected by the Chinese Trademark Act as well-known trademarks? ${ }^{133}$ So far, in the Chinese Trademark Act, the trademarks which are not well-known in China cannot be protected as unregistered trademarks. ${ }^{134}$

In China, the well-known trademarks system would be unfairly used for improper purposes. ${ }^{135}$ Many parties use the 'made' (through judicial or 
administration procedure) well-known trademarks on their products to popularize these products. The number of well-known trademarks may be regarded as political achievements of Chinese local government. ${ }^{136}$ Many Chinese companies used to propose false data to support their claims for well-known trademarks. ${ }^{137}$ Responding to the problems and in order to return well-known trademarks back to their correct positions, the doctrine of well-known trademarks has been established by judgments ${ }^{138}$ and practice. ${ }^{139}$ This doctrine has been inherited in the new law. ${ }^{140}$ Moreover, to tackle the above-mentioned problems, a drastic measure has been adopted in Article 14 of the new law, ${ }^{141}$ which lays down that well-known trademarks cannot be used on goods, packages or containers, or for advertising, exhibitions and other commercial activities. The unfair competition through using judicial-made well-known trademarks shall be fundamentally inhibited.

\section{Simplified Examination Process}

To reduce the cost and time of trademark registration, some measures have been taken in the new law such as, filing under more than one category of goods or services per trademark formula, ${ }^{142}$ electronic filing of trademark, ${ }^{143}$ time limit of trademark examination ${ }^{144}$ and trademark review submissions. ${ }^{145}$ Among these measures for simplified examination procedure, the most remarkable change rests in improving the system of opposition to trademark application and proclaiming the invalidation of registered trademark.

In the old law (2001), after the preliminary announcement of trademark application, anybody can file an opposition to the application for any kinds of reasons. ${ }^{146} \mathrm{CTO}$ will propose adjudication after an examination. If the opponent remains unconvinced by the adjudication, an application of re-examination will be filed to TRAB following a court procedure if the opponent remains still dissatisfied by the adjudication of TRAB. The long journey of application of trademark (the whole process took about 3-4 years) ${ }^{147}$ will most likely confuse trademark applicants, ${ }^{148}$ while conducive to the possible bad-faith opposition. In the case of bad-faith opposition, the opponent may prevent the trademark applicants from obtaining of trademark. ${ }^{149}$

To tackle above-mentioned problem, the new law has made some changes: 
(1) The opponents are limited to prior right-holders or interested parties; ${ }^{150}$ (2) if the opposition is not tenable, the opponent cannot file for review to TRAB; and (3) rather, proclaiming of invalidation of registered trademark can be filed to TRAB after the trademarks are registered. ${ }^{151}$ In other words, if the opposition is not tenable, the trademark shall be easily registered with the barriers of obtaining trademarks being reduced.

\section{Stronger Protection Efforts}

\section{A. A Heavier Punishment in Special Context and Punitive Damages}

The new law tries to protect trademark better through heavier punishment and monetary relief. Under the new law, the persons who have committed trademark infringement twice or more within five years or on those with other serious circumstances shall be imposed a heavier punishment. ${ }^{152}$ In the case of bad faith infringement where the circumstances are serious, the amount of monetary relief may be measured to a level that shall not only be exceeding three times, ${ }^{153}$ but also not less than the one time amount calculated according to the approaches such as plaintiff's damages ${ }^{154}$ or defendant's profits or reasonable trademark license royalties. The monetary relief shall cover the costs of the action. Where it is difficult to determine plaintiff's damages or defendant's profits or registered trademark license royalties, the People's Court shall make a decision on the monetary relief not exceeding RMB 3,000,000, taking into account the seriousness of the trademark infringement. ${ }^{155}$

\section{B. New Arrangement of Burden of proof}

The burden of proof in trademark infringement litigation is crucial to the plaintiff for adequate compensation. In the context of Lanham Act, e.g., if the plaintiff claims monetary relief on the defendant's profits, s/he shall be required to prove the defendant's sales only; defendant must prove all elements of cost or deduction claimed. $^{156}$ The arrangement of the burden proof in the Lanham Act concerns the reasonable arrangement of burden proof in trademark infringement litigation. The new law lays down the same job as follows. 
1. When the evidence is under the control of the defendant, if the plaintiff has fulfilled his/her obligation to supply evidence, the court may order the infringer to provide such evidences.

2 Where the defendant refuses to provide such information or provides false information, the court may determine the monetary relief at its discretion by taking into account the claims and the evidence provided by the plaintiff. ${ }^{157}$

In this circumstance, as a matter of fact, the burden of proof is on the defendant rather than the plaintiff. The new arrangement of burden of proof will decrease the burden of plaintiff for relief in the case of trademark infringement litigations.

\section{Suspension Procedures}

It is necessary to strengthen the protection of trademarks through the administrative forces relying on their efficiency. In contrast to judicial procedure, however the administrative protection may do more harm to the real right-holders when there are controversies over the ownership of a trademark. Therefore, a suspension procedure has been added in the new law. That is to say, in the process of the investigation initiated by ADIC, if there are controversies about the trademark or the right-holders have sued for a trademark infringement in a court, the investigation of ADIC may be suspended until the cause of the suspension does not exist. ${ }^{158}$

In addition, a contributory trademark infringement clause ${ }^{159}$ occurs in the new law. Following the clause, if the party willfully provides convenient conditions to help others in trademark infringement actions, s/he shall bear the liability of trademark infringement.

\section{Conclusion}

In accordance with the prior practice of Chinese trademark law, ${ }^{160}$ the new law has made fundamental changes that are consistent with the basic principles of trademark law. The new law, as a part of competition law, is more inclusive with a good faith clause which is the provision of competition law. In the future, if legitimate interests are not clearly defined as a right in trademark law, the interests 
may be protected by competition law. As non-traditional marks such as sound marks as legitimate sign of registered trademark have been accepted, they will be applied for registration. Without prior practices about non-traditional marks, administrative rules and juridical interpretations will be asked on registration and protection of nontraditional marks. The new law is more conducive to foreigners, especially rightholders of well-known trademark because it relies heavily on trademark use in obtaining trademark rights. The sleeping registered trademarks shall be awakened not by using registered trademarks as a trademark infringement defense. More trademarks shall be co-existing with the likelihood of confusion as the touchstone of trademark infringement. It is easier for the applicants to obtain registered trademarks based on the simplified examination procedure such as time limit of examination. The right-holders of trademarks will be more strongly protected with the stronger protection efforts in the new law such as punitive damages.

\section{REFERENCES}

1. Bohua Zhou [Secretary of the Administrative Department for Industry and Commerce (“ADIC")], Description on the Draft of Trademark Law of People's Republic of China Trademark Law, in the Eleventh NPC Standing Committee the Thirtieth Session Bulletin (May 2013).

2. See National People's Congress Standing Committee decided to amend "People's Republic of China Trademark Law" (Presidential Decree No. 6), Aug. 30, 2008, available at http:// www.gov.cn/zhengce/2013-08/30/content_2602289.htm (last visited on July 18, 2015).

3. Implementing Regulations of Chinese Trademark Act (2014).

4. E.g., Provisions of Well-Known Trademark Recognition and Protection (2003) (Issued by State Administration for Industry and Commerce of the People's Republic of China. No.5).

5. E.g., Interpretation on The Law Application In Trial of Trademark Civil Dispute Cases (2002) (Adopted by SPC in 2002. No.32), available at http://www.court.gov.cn/zscq/sfjs/201004/ t20100413_4048.html (last visited on Aug 2, 2015).

6. United Drug Co. v. Theodore Rectanus Co. 248 U.S. 90 (1918) at 97. (Trademark law is a species of the generic law of unfair competition.). For details, see J. MCCARTHY, I McCARTHY on Trademarks and Unfair Competition, $\$$ 2:7 2 - 12.1 (2006).

7. In the young trademark law, Equity acting "in aid of" and 'ancillary to' what it deemed to be a 'legal right' to have a particular trademark in such cases to protect the plaintiff's 'title' to trademarks, regardless of the question of deceit (Millington v. Fox, 3 Myl. \& C. 338 (1838)). However, the proprietary aspect of trademark protection has soon been changed as passing 
off or unfair competition. See F. Schechter, The Rational Basis of Trademark Protection, 40 Harv. L. Rev. 819-20 (1927).

8. Trademarks as property have been imbibed in Chinese trademark law with the approval of transfer and license of trademarks. See the Chinese Trademark Act (2001) arts. $39 \& 40$. In the new law, however, concerning the purpose of trademark of linking trademarks to goods, transfer and license of trademarks have been expressed with a more limited extent. Transfer of trademark with a likelihood of confusion, e.g., shall be rejected by CTO. See Chinese Trademark Act (2014) art. 42(3).

9. M. Lemley, The Modern Lanham Act and the Death of Common Sense, 108 YaLE L. J. 16945 (1998-9).

10. P. Brody, What's In A Nickname? Or, Can Public Use Create Private Rights? 95 TRADEMARK Rep. 1123 (2005).

11. U. Widmaier, Use, Liability, and the Structure of Trademark Law, 33 Hofstra L. Rev. 606 (2005).

12. Sony Ericsson Mobile Communications (China) Co., Ltd. has used the registered trademark ‘Sony Ericsson’ or ‘索尼爱立信’ on its products such as mobile phone. However, public usually call its products as 索爱 suó ài, a nickname of the Vice President and Head of Sony Ericsson Mobile Communications (China) Co., Ltd. In China Lu Jiansheng publicly stated that “we are not 索爱” and “please do not call us 索爱.” Liu Jianjia tries to register 索爱 on some goods or services. Beijing Higher People's Court stand on the side of Liu Jianjia. See Liu Jianjia vs. Sony Ericsson Mobile Communications (China) Co., Ltd.et al. (Trademark Administrative Dispute Appeal) [刘建佳与索尼爱立信移动通信产品 (中国) 有限公司等商标 行政纠纷上诉案], No. (2008) 717 of Administrative judgment of Beijing Higher People's Court, Final Judgment [北京市高级人民法院行政判决书] < available only in Chinese >.

13. Supra note 9 , at 1694.

14. In the dispute between Proview Technology (Shenzhen) Co., Ltd.[唯冠科技（深圳）有限公 司] and Apple for the mark 'iPad,' the former does not use the mark in commerce, however, Apple has used the mark for millions of dollars. The claim of the former for huge sum of damages has not been approved with a settlement on USD 60 Million. See Apple's $\$ 60$ million win iPad trademark registered trademark bullish [苹果6000万美元拿下iPad商标商标 抢注看涨], BeiJng Daily, July 3, 2012, available at http://tech.qq.com/a/20120703/000032. $\mathrm{htm}$ (last visited on July 18, 2014). < available only in Chinese>

15. The problem has been partly touched upon in the new Chinese trademark law. See Chinese Trademark Act (2014) art. 64.

16. The real injury of trademark infringement in all such cases can only be gauged concerning the function of a trademark. See supra note 7, at 825.

17. Chinese Trademark Act (2014) art. 7.

18. Chinese Anti-Unfair Competition Act (1993) art. 2(1).

19. Trademark law is crafted to enable the public to identify easily a particular product from a 
particular source with an effect of fair competitive market. See supra note 9, at 1695.

20. There is no provision in the old Chinese Trademark Act regulating the conflict between a trademark and a business name. However, the judicial interpretation of SPC has addressed the problem, albeit indirectly. See Judicial Interpretation on the Trail of Conflict between Registered Trademark, Business Name and the Prior Rights of SPC 4 (No. 3 (2008)).

21. Chinese Trademark Act (2014) art. 58.

22. Qualitex Co. v. Jacobson Prods. Co., 514 U.S. at 162 (1994).

23. D. Bumpus, Bing, Bang, Boom: An Analysis of In re Vertex Group LLC and the Struggle for Inherent Distinctiveness in Sound Marks Made During a Product's Normal Course of Operation, 21 Fed. CiR. B. J.249 (2012).

24. Chinese Trademark Act (2001) art. 8. It reads: "Any visible signs being able to identify and distinguish goods [or services]originated from different natural persons, legal persons or other kinds of organizations including words, devices, letters, numbers, three-dimensional marks and color combinations or combination thereof can be registered as trademark."

25. Certain sounds are unregistrable, such as those concerning pubic interests such as national anthem and military song. See Chinese Trademark Act (2014) art. 10(1).

26. Non-traditional trademarks are registrable in many legislations such as those in France (Intellectual property code of France of 1992, L.711-1) and Germany (Act on the Protection of Trademarks and Other Marks of Germany of 1998, art. 3).

27. Chinese Trademark Act (2014) art. 8. It reads: "Any signs being able to identify and distinguish goods [or services]originated from different natural persons, legal persons or other kinds of organizations including words, devices, letters, numbers, three-dimensional marks, color combinations, sound marks and etc. or combination thereof can be registered as trademark."

28. K. McCormick, “Ding” You Are Now Free To Register That Sound, 96 Trademark Rep. 1105 (2006).

29. Id. at 1110. [Emphasis added]

30. In the US, only a specimen, a description of the mark, and proof of use will satisfy the requirements of application of sound marks. See id. at 1106.

31. Implementing Regulations of Chinese Trademark Act (2014) art. 13(5). It reads: "Sound marks should be registered following the statement in the application, a required specimen of sound, a description of the mark and a description of the ways of use of the marks. Stave or notation should be used plus literary descriptions to describe the sound. When the sound cannot be described by stave and notation, literary descriptions should be used to describe the sound. The description of the sound should be identical to the specimen of the sound."

32. Supra note 28, at 1106.

33. Id. at 1110.

34. Id. at 1111.

35. Id. 
36. Id.

37. In re Gen. Elec. Broad. Co., 199 U.S.P.Q. (BNA) 563 (T.T.A.B. 1978).

38. Supra note 28, at 1107.

39. Wal-Mart Stores, Inc. v. Samara Bros., 529 U.S. at 210-1 (2000).

40. Supra note 37 , at 563.

41. The quack of a duck is a commonplace sound which will be registrable only upon proof of acquired distinctiveness. See Ride the Ducks LLC v. Duck Boat Tours, Inc., 75 U.S.P.Q.2d (BNA) 1269 (E.D. Pa. 2005).

42. Supra note 37 , at 563.

43. Supra note 28, at 1109.

44. Supra note 37 , at 563.

45. NG-Loy Wee Loon, Trade Marks, Language And Culture: The Concept of Distinctiveness and Publici Juris, Sing. J. Legal Stud. 508 (2009).

46. U.S. Trademark Reg. No. 1395550.

47. In re Vertex Group LLO, 89 U.S.P.Q.2d (BNA) 1694 (T.T.A.B. 2009).

48. M. Lawry \& J. Dickerson, The Curse of Invisibility, TRADEMARK World 26 (2004)

49. Supra note 28, at 1119.

50. Id. at 1109.

51. Supra note 23, at 253.

52. Supra note 28, at 1105.

53. Id. at 1109 .

54. Id. at 1108 \& 1113 .

55. Supra note 23, at 253-4.

56. A. Zelnick, The Doctrine of Functionality, 73 Trademark Rep. 128 (1983).

57. Inwood Labs. Inc. v. Ives Labs. Inc., 456 U.S. at 844 \& 850 (n.10) (1982).

58. C. O'Hara, Product Configuration, Dilution, and Fair Use, SG080 ALI-ABA 471 (2002).

59. Qualitex Co. v. Jacobson Prods. Co., 514 U.S. 165 (1995), re-cited from InwoodLabs, Inc., 456 U.S. at 850 (n. 10).

60. In re Morton-Norwich Products, Inc., 671 E2d 1332, 1340-1341 (C.C.P.A. 1982). See supra note 23, at 257.

61. N. Pisarsky, PoTAYto-PoTAHto-Let's Call the Whole Thing off: Trademark Protection of Product Sounds, 40 Conn. L. Rev. 806-8 (2007-8).

62. Kawasaki Motors Corp. U.S.A. v. H-D Michigan Inc., 43 U.S. PQ.2d (BNA) 1521 (T.T.A.B. 1997).

63. Id. at 1525 .

64. TrafFix Devices, Inc. v. Mktg. Displays, Inc., 532 U.S. at 34 (2001).

65. Supra note 28, at $1108 \& 1120$.

66. Brunswick Corp. v. British Seagull Ltd., 35 F.3d 1257, 1531 (Fed. Cit. 1994).

67. Supra note 23, at 265. 
68. J. Nelson \& P. Jacobson, Composite Trademarks: Deconstructing the Similarity of Marks Element in a Trademark Infringement Action, 72 Def. Counsel J. 349 (2005).

69. The marks should be compared in their entireties because consumers view a mark as a whole rather than as dissected parts. See Fruit of the Loom, Inc. v. Girouard, 994 F.2d 1362 (9th. Cir. 1993).

70. Chinese Trademark Act (2014) art. 8. It reads: "Any signs being able to identify and distinguish goods [or services]originated from different natural persons, legal persons or other kinds of organizations including words, devices, letters, numbers, three-dimensional marks, color combinations, sound marks and etc. or combination thereof can be registered as trademark."

71. Flavor is never inherently distinctive. See In re N.V. Organon, 79 U.S. P.Q.2d (BNA) 1650 (T.T.A.B. 2006).

72. United Drug Co. v. Theodore Rectanus Co. - 248 U.S. at 97 (1918).

73. McCarthy, supra note 6, §3:2 3-6.

74. Peng Xuelong, Seeking a Reasonable Balance between Registration and Use in the Obtaining of Exclusive Rights of Trademark [寻求注册和使用在商标法中的合理平衡], $3 \mathrm{~J}$. LEGAL STUD. [法学研究] 151 (2010)<available only in Chinese>

75. Trade-Mark Cases, 100 U.S. at 82 \& 94 (1880).

76. Supra note 74 , at 157.

77. Maybe the registration-dominated formula is conducive to the regulation of the bona fide use of trademarks. However, if first-to-file doctrine is partial adhered without concerning trademark use, the end of trademark law shall not be achieved.

78. Germany Trademark Act art. 4. See supra note 74, at 158.

79. Supra note 11, at 606.

80. Chinese Trademark Act (2014) art. 49(2).

81. Supra note 11, at 618.

82. Chinese Trademark Act (2014) art. 48. It reads: "The use of trademarks as mentioned in this Law and the present Regulation refers to affixing trademarks to commodities, commodity packages or containers as well as commodity exchange documents or using trademarks to advertisements, exhibitions and other commercial activities to indicate the sources of the commodities."

83. Chinese Trademark Act (2014) art. 4 (1).

84. The trademarks which have not been for used consecutive three years (Russia Trademark, Service Mark and Indications of Source Act of 1992 art. 32(3)) or five years (Italy Trademark Act of 1996 art. 42(1)) can be cancelled.

85. Chinese Trademark Act (2014) art. 49(2).

86. 15 U.S.C. $\S 1127$ (2012).

87. W. McGeveran, Rethinking Trademark Fair Use, 94 Iowa L. Rev. 56 (2009).

88. Supra note 7, at 819-25. 
89. S. Dogan \& M. Lemley, Grounding Trademark Law through Trademark Use, 92 Iowa L. REv. 1677 (2007).

90. See Interactive Products Corp. v. A2Z Mobile Office Solutions, Inc. 326 F.3d 687 (6th Cir. 2003).

91. Supra note 11 , at 631.

92. United Drug Co. v. Theodore Rectanus Co. - 248 U.S. at 98 (1918).

93. Du Ying, Outline of Protection of Prior Used Unregistered Trademark: Comments on the Third Revision of Chinese Trademark Law [在先使用的未注册商标保护论纲-兼评<商标法>第 三次修订], 3 JuRIST [法学家]124-6 (2009). < available only in Chinese>

94. E.g, Chinese Trademark Act (2001) art. 29.

95. Id. arts. 13(1), $31 \& 41(1)$.

96. If a trademark has been practically used in China and has been known to a range of relevant public, the trademark can be deemed as a widely-known trademark to some extent. See Opinions on Trial of Trademark Authorization Issues of SPC (No. 12 (2010)) ๆ 18(2). There are different prerequisites for protection of prior users of trademarks. In Italy trademark law, e.g., the owners of non-widely-known or local-well-known unregistered trademarks are entitled to continue use their marks in the same territory. See Italy Trademark Act (1996) art. 9.

97. If the applicant know or should know the used widely-known trademark in some extent in some extent, he still tries to register the trademark as his own. It is unfairly. See Opinions on Trial of Trademark Authorization Issues of SPC (No. 12 (2010)) ๆ 18(1).

98. In contrast to well-known trademarks, right holders of a widely-known trademark to some extent cannot block others from registering the trademark for non-identical and non-similar goods or services. See Opinions on trial of trademark authorization issues of SPC (No. 12 (2010)) ब 18(3).

99. CTO, Standard of Trademark Trial [商标审理标准] pt. 5 (2005). In the new Chinese trademark law, the unfairly registered trademark on other party's prior used trademark may be invalided. It is worth noting that the new Chinese trademark law has absorbed the essence of the provisions of CTO to protect the prior used unregistered trademark in a special context (i.e. the trademark applicants know the existing of the prior used unregistered trademark). See Chinese Trademark Act (2014) art. 15. The above provision aims to protect the prior used unregistered trademark against the bad-faith registration of the trademark. In contrast, however, the new law only prohibit the bad-faith trademark registration in which the applicant know (not including should know) the prior-unregistered trademark.

100. Chinese Trademark Act (2014) art. 59(3). It reads: "Where an identical or similar trademark has been used in connection with the same goods or similar goods by others before the registrant's application, the exclusive right holder of said registered trademark shall have no right to prohibit other people from using the aforesaid trademark from continuous use of such trademark within the original scope, but may request its users to add 
proper marks for distinction."

101. There is similar settlement about the trademark prior user and the junior registrant in Japanese trademark law. See Japanese Trademark Act (2008) art. 32.

102. Handong Wu, Intellectual Property Law [知识产权法] 304 (2007) <available only in Chinese>.

103. Xiaoging Feng, Theory of Balancing in Law of Intellectual Property Rights [知识产权 法利益平衡理论] 142 (2006). < available only in Chinese>

104. Yang Li, Interpretation of the Prior Right in Trademark Law Basing on the Law of Intellectual Property Right [商标法中在先权利的知识产权法解释], 5 LEGAL SCI. [法律科学] 49 (2006). <available only in Chinese>

105. In Germany, in general, the prior user has an exclusive right on the mark. However, if the trademark owner knows but is silent that the bona fide junior registrant consecutively uses the mark for 5 years, his exclusive right shall be limited with the registrant continuing using the mark on the registered goods or services. See Act on the Protection of Trademarks and Other Marks of Germany (1998) art. 21(1).

106. As a matter of fact, other than a likelihood of confusion, if there is a likelihood to cause a mistake, or to deceive as to the affiliation, connection, or association of such person with another person, or as to the origin, sponsorship, or approval of his or her goods, services, or commercial activities by another person does exist, the prior user should be entitled to sue the latecomer for trademark infringement. See 15 U.S.C. § 1125 (2012).

107. Supra note 10, at 1124.

108. Priority principle should be in applied in the special context of a legislation which usually should be limited if the prior user shall be denied in the claim to exclude others using the identical or similar marks on the identical or similar goods or services because of laches in cases where the equities weigh in favor of a junior user's good faith trademark use. See McCarthy, supra note 6, at v. $5 \S \S 26: 57,26-99$. This is also true in Germany. See Act on the Protection of Trademarks and Other Marks of Germany (1998) art. 21.

109. The co-existing registered trademarks shall be approved if a trademark has been created by different parties through using the identical or similar mark on the identical or similar goods or services in remote territories (i.e. likelihood of confusion does not exist). See 15 U.S.C. § 1152(d) (2012). In India, the bona fide co-existing of registered or un-registered trademark is approved by law. See India Trademark Act (1999) art. 12.

110. United Drug Co. v. Theodore Rectanus Co. 248 U.S. 97-8 (1918).

111. The property right of a trademark is called as a kind of "quasi-property right" which is focusing on the protection of consumers rather than protection of producers as an incentive to product innovation such as copyright and patent. See Bonito Boats, Inc. v. Thunder Craft Boats, Inc., 489 U.S. 141, 103 L.Ed.2d 118, 109 S. Ct. 971, 9 U.S.P.Q. 1854-5 (2d. 1989).

112. Supra note 7 , at 822 .

113. Transclean Corp. v. Bridgewood Services, Inc., 290 F.3d 1364 (Fed. Cir. 2002). 
114. International Order of Job's Daughters v. Lindeburg and Company, 633 F.2d 912, 208 U.S.P.Q. 718 (9th. Cir. 1980).

115. The Lanham Act usually is interpreted as monetary relief for plaintiff should be based on proving the existing of actual confusion and/or the defendant's willfulness. See D. Almeing, The Infringement-Plus-Equity Model: A Better Way to Award Monetary Relief in Trademark Cases, 14 J. Intellectual Prop. L. 207 (2007).

116. Chinese Trademark Act (2014) art 64.

117. It is worth noting that in the case of trademark dilution, likelihood of confusion is not the requirement. See 15 U.S.C. $\S 1125$ (c) (2012).

118. A. Makulilo, Likelihood of Confusion: What is the Yardstick? Trade Mark Jurisprudence in Tanzania, 7 J. Intellectual Prop. L. \& Practice 350 (2012).

119. Survivor Media, Inc. v. Survivor Prod., 406 F.3d 625, 631 (9th. Cir. 2005); Thane Int'1, Inc. v. Trek Bicycle Corp., 305 F.3d 894 (9th Cir. 2002). See supra note 68, at 347.

120. Supra note 118 , at 350 .

121. Supra note 68 , at 347.

122. Walt Disney Productions v. Air Pirates, 581 F.2d 751, 759 (9th. Cir. 1978).

123. Supra note 67 , at 348.

124. B. Pattishall, Trademarks and the Monopoly Phobia, 50 Mich. L. Rev. 978 (1951).

125. Chinese Trademark Act (2014) art 57.

126. S. Lovenworth \& K. Dittrich, Protection of Well Known Trademarks in China, 78 J. Pat. \& Trademark OfF. SOC'y 183(1996).

127. Honguun Yao, Research on Legal Issues Related to Well-Known Trademarks [驰名商标 相矢法律问题研究] 21 (2009).

128. The Implementation Rules of the Chinese Trademark Act (1993) art. 25 (2)

129. Supra note 127 , at 22.

130. Paris Convention for the Protection of Industrial Property (1979) art. 6bis. See also Jin Zhang, Thoughts on the special protection of well-known trademarks 对驰名商标特殊保护 的若干思考], 2 F. PoL. SCI. \& L. (J. CUPL) [政法论坛 (中国政法大学学报)] 35 (2000).

131. In Article 6(2) of the Paris Convention, the protection of well-known trademarks is limited to identical or similar goods. In Article 16 of TRIPs, however, the protection of well-known trademarks is expanded to non-similar goods and services.

132. Chinese Trademark Act (2001) arts. 13 \& 14.

133. CASTEL FRERES SAS, a wine manufacturing and sales company, has not proven that it has so widely used the trademark 'CASTEL' in mainland China where the trademark occurs as a well-known trademark. Daozhi Li, the rights holder of '卡斯特,' is not considered as bad faith registering the trademark '卡斯特' translated from 'CASTEL.' See CASTEL FRERES SAS v. TRAB (Trademark Administrative Dispute), No. 2834 (2010) of Administrative Judgment of Beijing First Intermediate People's Court, Preliminary Judgement [北京市第一中级人民法院行政判决书]. < available only in Chinese> 
134. The well-known trademarks mean the widely known trademark by the relevant public in China. See Judicial Interpretation of the Application of Law in the Cases involving WellKnown Trademark Protection and Disputes of SPC (2009) art. 1.

135. Xiangjun Kong, Understanding and Application of the Supreme People's Court's Judicial Interpretation about Intellectual Property Rights 孔祥俊, <最高人民法院知识产权司法解释理 解与适用>, China Legal Publishing House [中国法制出版社] 137 (2012). <available only in Chinese>

136. Xingliang Tao, Misunderstanding of the Protection of Well-Known Trademark in China, Its Way [我国驰名商标保护的误区及其出路], China Intellectual Property Newspaper [中国 知识产权报] Nov. 21, 2007. < available only in Chinese>

137. Xinian Tao, Investigation of the Flood of Well-Known Trademarks [“驰名”商标泛滥调查], 2 L. \& Soc'y [法治与社会] 70(2009).

138. Supra note 1.

139. See Judicial Interpretation of the Application of Law in the Cases involving Well-Known Trademark Protection and Disputes of SPC (2009) arts. 2 \& 3.

140. Chinese Trademark Act (2014) arts. 14(2), 14(3) \& 14(4).

141. Id. art. 14(5).

142. In the old Chinese trademark law (2001), one trademark application was limited to one category (International Classification of Goods and Services for the Purposes of the Registration of Marks (10th ed. 2011) of goods or services. See Chinese Trademark Act (2001) arts. 20 \& 21.In practice, the official fee of a trademark registration is RMB800. The agency fees are about RMB500-1000. If a company registers a trademark on all of the categories of goods or services, the total fees will approximate to RMB60,000 which will place a large burden on the trademark applicants. See Twelve major highlight of the Chinese new trademark law implemented from May 1, the interpretation of the Municipal Trade and Industry Bureau [新<商标法> 5月1日起实施市工商局解读十二大亮点], available at http://www.10yan.com/2014/0428/91205.shtml (last visited on May 24, 2014.) <available only in Chinese>. A change has been made in the new Chinese trademark law. See Chinese Trademark Act (2014) art. 22(2). It reads: "Trademark applicants may register one trademark on more-than-one categories of goods in per application.” In the new Chinese trademark law, in one filing, trademark applicants may register one trademark on all of the categories of goods or services which will greatly reduce the burden on enterprises.

143. In the digital era, occurring of new technologies call for electronic filing of trademark lawful. Response to the digital context, the new Chinese trademark law has accepted electronic filing of trademark as the lawful methods of filing trademark. See Chinese Trademark Act (2014) art. 22 (3). It reads: "Trademark registration and other relevant documents can be made in writing or data messages."

144. The time limit of examination of trademarks application by CTO on the applicants of trademark is first clearly defined in the new Chinese trademark law. See Chinese 
Trademark Act (2014) art. 28. The review of TRAB on the refused trademark application is nine months. See Chinese Trademark Act (2014) art. 34. Particularly, in the case of the review procedure of TRAB, the deadline may be extended for three months, however. The time limit of examination of opposition to the trademark application should be twelve months, in special cases, while the deadline may be extended for six months. See Chinese Trademark Act (2014) art. 35(1). The provisions of the time limit will improve the current lengthy trademark registration. For the interests of the right-holders of registered trademark, in the new Chinese trademark law, the application of renewal for the validity of trademark (trademark renewal procedure) may be proposed within twelve months (6 months in the old Chinese trademark law, however, according to Article 38 of the Chinese Trademark Act (2001)), before the expiration of the registered trademark. See Chinese Trademark Act (2014) art. 40(1).

145. Following the successful practice of patent review submissions, trademark review submissions are added in the new Chinese trademark law which will improve the quality of examination of trademark registration. See Chinese Trademark Act (2014) art. 29.

146. Chinese Trademark Act (2001) art. 30.

147. See The new Chinese trademark law will be implemented in May 1, 10 highlights of the new law [新商标法5月1日实施, 详解新商标法10大亮点], available at http://www.edu1488. com/article/2014-5/13100828.shtml, (last visited on May 24, 2014). <available only in Chinese>

148. Supra note 1.

149. Sun Bingwang [officer of CTO], Bad-Faith Opposition Is Robbery [恶意异议无异拦路抢劫], 9 ChinA TRADEMARK [中华商标]24 (2005) <available only in Chinese>

150. Chinese Trademark Act (2014) art. 33.

151. Id. art. 35(2).

152. Id. art. $60(2)$.

153. In most states of the US, under State Law, punitive damages of trademark infringement shall be awarded in certain limited extent. See Mccarthy, supra note 6, §30:95 §30:96 30212-16 (2006).

154. In the context of Lanham Act, the monetary relief basing on damages may be above the amount found as the actual damages, not exceeding three times such amount. See supra note 115 , at 210 .

155. Chinese Trademark Act (2014) art. 63.

156. Supra note 115 , at 210.

157. Chinese Trademark Act (2014) art. 63(2).

158. Id. art. 62(3).

159. Id. art. 57.

160. Many of the 'new' clauses have been stipulated in the prior regulations such as the regulations against bad faith registration. See Chinese Trademark Act (2014) art. 15. It has occurred in Standard of Trademark Trial of CTO (2005). 